Info Artikel Diterima Agustus 2017

Disetujui Januari 2018

Dipublikasikan Oktober 2019

\title{
TAMPILAN GULA DARAH , LAKTOSA DAN PRODUKSI SUSU SAPI PERAH LAKTASI YANG DISUPLEMENTASI BAKING SODA (NaHCO3)
}

\author{
DISPLAY OF BLOOD SUGAR, LACTOSE AND PRODUCTION OF \\ DAIRY MILK WHICH SUPPLEMENTED WITH BAKING SODA \\ $\left(\mathrm{NaHCO}_{3}\right)$
}

\author{
R.C Kurniawan, C. Budiarti dan S.M Sayuthi \\ Fakultas Peternakan dan Pertanian Universitas Diponegoro, Semarang
}

Email: raymondusck@gmail.com

\begin{abstract}
This study aims to determine the effect of the addition of baking soda as a supplement of dairy cattle feed on blood sugar, lactose, and milk production. This study used the dairy cow FH lactation of the 2nd lactation period of 5th month lactation and 6th lactation of 12 with 2-3 years old. Dairy cow FH lactation has a weight of $389.17 \pm 27 \mathrm{~kg}$. The treatment used was the addition of baking soda with the level of $0.8 \%$ and $1.0 \%$. This study used a ration consisting of soybean meal, corn, brand, meat bone meal, lactoplus and forage grass uganda feed. This study used a complete randomized design consisting of 3 replication and 4 treatments. The data obtained were analyzed using variance analysis and $\mathrm{F}$ test at $5 \%$ level. The results showed that the addition of baking soda as supplement had no significant effect on blood sugar, lactose, and milk $(\mathrm{P}>0,05)$, but it can increase milk production without supplementation (T0). The conclusion of this research is that the addition of baking soda at the level of 0.8 and $1.0 \%$ has no significant effect on blood sugar, lactose, and cow milk production.
\end{abstract}

Keywords: Baking soda,blood sugar,lactose and production of diary milk.

\begin{abstract}
ABSTRAK
Penelitian ini bertujuan untukmengetahui pengaruh penambahan baking soda sebagai suplementasi pakan sapi perah terhadap kandungan gula darah, laktosa, dan produksi susu. Penelitian ini menggunakan materi sapi perah $\mathrm{FH}$ laktasi periode ke II bulan laktasi ke 5 dan 6 sebanyak 12 ekor dengan umur 2-3 tahun. Sapi perah FH laktasi memiliki bobot badan 389,17 $\pm 27 \mathrm{~kg}$. Perlakuan digunakan yaitu penambahan baking soda dengan level 0,8\% dan 1,0\%. Penelitian ini menggunakan ransum yang terdiri dari bungkil kedelai, jagung, bekatul, meat bone meal, lactoplus dan pakan hijauan rumput gajah. Penelitian ini menggunakan rancangan acak lengkap yang terdiri dari 3 perlakuan 4 ulangan. Data yang diperoleh dianalisis menggunakan analisis ragam dan uji $\mathrm{F}$ pada taraf 5\%. Hasil menunjukkan bahwa penambahan baking soda sebagai suplementasi tidak berpengaruh nyata terhadap kandungan gula darah, laktosa, dan produksi susu $(\mathrm{P}>0,05)$, tetapi dapat meningkatkan produksi susu dibanding tanpa suplementasi (T0). Kesimpulan penelitian ini penambahan baking soda pada level
\end{abstract}


0,8 dan $1,0 \%$ tidak berpengaruh nyata terhadap kandungan gula darah, laktosa, dan produksi susu sapi.

Kata kunci: Baking soda, gula darah, laktosa, produksi susu.

\section{PENDAHULUAN}

Sapi Friesian Holstein $(\mathrm{FH})$ merupakan sapi perah yang produksi susunya tinggi dengan persentase kadar lemak yang rendah apabila dibandingkan dengan bangsa sapi perah lainnya. Produksi susu sapi perah dipengaruhi oleh faktor genetik (sifat keturunan) dan faktor lingkungan. Kemampuan sapi perah dalam memproduksi susu dipengaruhi oleh $30 \%$ genetik dan $70 \%$ lingkungan. Manajemen pemeliharaan meliputi manajemen pemberian pakan, manajemen pemerahan, pengaturan perkawinan, manajemen perkandangan dan sanitasi lingkungan dan penanganan penyakit serta pencegahannya.

Menurut Suhendar dkk (2008), komposisi rata-rata susu sapi terdiri dari: Air 83,3 \%, protein 3,2\%, lemak 4,3\%, karbohidrat 3,5\%, kalium 4,3 mg/100 gr, kalsium 143,3 mg/ $100 \mathrm{gr}$,fosfor $60 \mathrm{mg} / 100 \mathrm{gr}$, besi 1,7 mg/100 gr, vitamin A, SI 130, Vitamin B1 0,3 mg/100 gr dan vitamin C $1 \mathrm{mg} / 100$ gr. Sumudhita (1989) menambahkan bahwa komposisi susunan normal pada susu sapi terdiri dari air $(87,20 \%)$, lemak $(3,70 \%)$, protein $(3,50 \%)$, laktosa $(4,90 \%)$.

Susu merupakan hasil utama dari ternak perah, dengan kandungan gizi yang lengkap dan sangat dibutuhkan oleh masyarakat. Nilai gizi yang terkandung antara lain karbohidrat, protein, lemak, mineral, kalsium, vitamin A, asam amino esensial maupun non esensial, dan sebagainya. Produksi susu yang dihasilkan untuk memenuhi kebutuhan masyarakat di Indonesia masih sangat rendah, karenanya diperlukan peningkatan hasil, baik kualitas maupun kuantitasnya. Sapi perah merupakan salah satu ternak ruminansia karena memiliki lambung ganda. Pada lambung ternak ruminansia terdapat rumen yang dapat melakukan proses fermentasi oleh mikroorganisme rumen. Mikroba rumen bertugas untuk mendegradasi nutrien-nutrien pakan dalam rumen sehingga dapat dimanfaatkan oleh tubuh. Adanya mikroba ini menyebabkan ternak ruminansia dapat mencerna pakan yang mengandung serat tinggi serta mampu mengubahnya menjadi Volatile Fatty Acid (VFA) yang menghasilkan asam asetat, butirat, propionat dan energi sebagai bahan dasar pembentukan lemak susu. Kemudian Asam asetat dan asam butirat akan masuk ke peredaran darah menuju hati untuk diubah menjadi asam lemak, selanjutnya masuk kedalam sel-sel sekresi ambing untuk sintesis lemak susu.

Aktifitas mikroba rumen sangat mempengaruhi $\mathrm{pH}$ yang ada di rumen. $\mathrm{pH}$ yang tidak sesuai pada rumen akan menghambat proses fermentasi mikroba rumen. Sehingga produk VFA akan menurun. Penurunan VFA akan berimbas pada penurunan kualitas produksi susu karena asam asetat dan butirat pada VFA juga menurun dan jumlah asam asetat dan butirat yang sedikit ini berdampak terhadap kadar lemak susu yang rendah. Penurunan $\mathrm{pH}$ dalam rumen juga menyebabkan zat vasokonstriksi seperti histamin dan endotoksin akan dilepaskan ke sirkulasi sistemik. Zat ini dapat menyebabkan peradangan dan akhirnya menghancurkan microvasculature dari corium di kuku, yang mengarah ke 
laminitis. Oleh karena itu diperlukan pencegahan agar tidak terjadi penurunan $\mathrm{pH}$ rumen salah satunya dengan penggunaan larutan buffer untuk menjaga kondisi rumen tetap stabil yaitu dengan natrium bikarbonat.

Natrium bikarbonat $\left(\mathrm{NaHCO}_{3}\right)$ atau yang biasa disebut Baking Soda merupakan senyawa yang berfungsi sebagai buffer. Suplementasi Baking soda ke dalam pakan diharapkan dapat menstabilkan $\mathrm{pH}$ rumen, sehingga mikroba rumen dapat bekerja secara optimal serta hasil lemak susu juga optimal.

\section{BAHAN DAN METODE}

Penelitian ini menggunakan materi sapi perah FH laktasi sebanyak 12 ekor dengan umur 2-3 tahun. Sapi perah FH laktasi memiliki bobot badan 389,17 \pm 27 kilogram. Penelitian ini menggunakan ransum yang terdiri dari konsentrat, cargill, dan hijauan rumput gajah. Baking soda dicampur dengan konsentrat lalu dihomogenisasi sampai tercampur rata. Pengamatan parameter produksi susu dilakukan 2 kali dalam sehari ketika pemerahan pagi dan sore. Pengambilan sampel sebanyak $10 \mathrm{ml}$ susu diakhir penelitian. Penelitian ini menggunakan rancangan acak lengkap yang terdiri dari 3 perlakuan 4 ulangan.

Perlakuan yang digunakan ada 4 yaitu :

T0: Pemberian pakan tanpa suplementasi baking soda

T1: Pemberian pakan dengan penambahan baking soda $0,8 \%$

T2: Pemberian pakan dengan penambahan baking soda 1,0\%

Tabel 1. Hasil Analisis Proksimat Bahan Pakan dan Komposisi Ransum

\begin{tabular}{|c|c|c|c|c|c|c|}
\hline Bahan Pakan & $\begin{array}{c}\text { Komposisi } \\
\text { rasum }\end{array}$ & $\mathrm{BK}^{*}$ & $\mathrm{PK}^{*}$ & $\mathrm{LK}^{*}$ & $\mathrm{SK}^{*}$ & $\mathrm{TDN}^{* *}$ \\
\hline & & \multicolumn{5}{|c|}{--------------------- $\%$--------------------- } \\
\hline Rumput Gajah & & 15,32 & 7,80 & 2,86 & 23,33 & 53,34 \\
\hline Konsentrat & & 90,22 & 10,22 & 4,14 & 17,12 & 67.99 \\
\hline Pellet (Cargill) & & 86,60 & 13,69 & 4,22 & 16,06 & 85,44 \\
\hline \multicolumn{7}{|c|}{ Komposisi Ransum pakan } \\
\hline & \multicolumn{6}{|c|}{------------------------ \% ----------------------- } \\
\hline Rumput Gajah & 43 & 8,38 & 3,93 & 1,23 & 10,03 & 22,73 \\
\hline Konsentrat & 26 & 21,76 & 3,18 & 1,08 & 4,45 & 16,86 \\
\hline Pellet (Cargill) & 31 & 26,80 & 4,91 & 1,31 & 4,98 & 25,34 \\
\hline Total & 100 & 56,94 & 12,01 & 3,61 & 19,46 & 64,93 \\
\hline
\end{tabular}

Keterangan :

* Hasil Analisis Proksimat

$* *$ Dihitung dengan rumus TDN $(\%)=37,937-1,018(\mathrm{SK})-4,886(\mathrm{LK})+0,173$

$(\mathrm{BETN})+1,042(\mathrm{PK})+0,015\left(\mathrm{SK}^{2}\right)-0,058\left(\mathrm{LK}^{2}\right)+0,008(\mathrm{SK})(\mathrm{BETN})+0,119$

$(\mathrm{LK})(\mathrm{BETN})+0,038(\mathrm{LK})(\mathrm{PK})+0,003\left(\mathrm{LK}^{2}\right)(\mathrm{PK})$ Hartadi et al. $(1990)$

Parameter yang diukur :

1. Gula darah

Pengambilan darah dilakukan pada minggu ke empat. Pengambilan darah dilakukan $3-4$ jam setelah pemberian makanan pada pagi hari pada minggu ke empat. Contoh darah diambil dari vena caudalis menggunakan 
venoject berisi heparin. Selanjutnya, venoject dibungkus dengan plastik lalu disimpan dalam termos es berisi es batu selama pengangkutan. Setelah di Laboratorium, plasma darah dipisahkan dari butiran darah dengan cara disentrifugasi dengan kecepatan 3.000 putaran per menit (rpm) selama 30 menit. Selanjutnya hasil sentrifugasi segera dipindahkan ke dalam tabung reaksi $10 \mathrm{ml}$ dengan menggunakan pipet lalu disimpan pada suhu $4^{\circ} \mathrm{C}$ untuk analisis komponen kimia darah.

2. Laktosa susu

Kandungan laktosa susu dapat diukur dengan menggunakan metode Nelson yang ditemukan oleh Fiona Frais dari Inggris pada tahun 1972 (Benerjee, 1982). Prinsipnya adalah sebagai berikut: laktosa yang merupakan karbohidrat utama di dalam susu direduksi oleh katalis, gugus karbonil dari laktosa bereaksi dengan kupri menghasilkan cupri oksida $(\mathrm{CuO})$ yang berwarna merah. Senyawa ini dengan pemanasan akan bereaksi dengan asam fosfomolibdat yang berwarna biru. Serapannya diukur dengan Spektrofotometer pada panjang gelombang 630 nanometer. Cara kerja penentuan kandungan laktosa susu adalah sebagai berikut : ke dalam labu $100 \mathrm{ml}$ yang telah berisi $1 \mathrm{ml}$ susu bebas lemak ditambahkan 2 ml Natrium Tungstat, kemudian secara perlahan-lahan sambil dikocok ditambahkan $2 \mathrm{ml} \mathrm{H}_{2} \mathrm{SO}_{4}$. Larutan tersebut diencerkan hingga batas dan dibiarkan selama 5 menit kemudian disaring dengan kertas saring whatman no. 42 ke dalam tabung Folin-Wu di pipet $1 \mathrm{ml}$ filtrat, kemudian ditambah $1 \mathrm{ml}$ aquades, $2 \mathrm{ml}$ standar glukosa yang mengandung 0,06 $\mathrm{mg}$ laktosa. Membuat standar laktosa dari larutan baku (yang mengandung 1 gr/100 ml laktosa) dengan cara memipet $3 \mathrm{ml}$ larutan ini kedalam labu ukur $100 \mathrm{ml}$, kemudian dengan larutan asam benzoat 0,2\% hingga batas. Kedalam masing-masing tabung Folin-Wu ditambahkan $2 \mathrm{ml}$ reagen $\mathrm{Cu}$ alkalis, lalu dipanaskan dalam penangas air dan dididihkan selama 8 menit dan didinginkan sambil dikocok ditambahkan reagen posmopolitan, dibiarkan 1 menit lalu diencerkan dan dibaca absorbsinya pada $630 \mathrm{~nm}$. Rumus yang digunakan untuk mengetahui kandungan laktosa susu adalah sebagai berikut : $\frac{A x}{A s t}=\frac{C x}{C s t} \mathrm{Cx}$ atau kandungan laktosa di dalam $0,1 \mathrm{ml}$ susu adalah : $\frac{A x}{A s t}=\frac{0,6}{1000}$ gram $/$ laktosa. Kandungan laktosa $(\mathrm{g} / 100 \mathrm{ml})$ adalah $=$ $\frac{A x}{A s t} \times \frac{K s t}{1000} \times \frac{100}{0,01}$

Keterangan: $\mathrm{Ax}=$ serapan laktosa didalam susu

Ast $=$ serapan laktosa standar

$\mathrm{Cx}=$ kandungan laktosa di dalam susu $(\mathrm{mg} / 100)$

3. Produksi susu:

Pengambilan sampel air susu dilakukan pada minggu ke 4. Air susu yang diambil untuk dijadikan sampel adalah susu dari pemerahan pagi dan sore yang sudah dihomogenkan. Adapun jumlah susu yang diambil pada pemerahan pagi/sore yaitu: 
Sample susu $=\frac{\text { produksi (pagi atau sore) }}{\text { produksi total }} \times$ jumlah sample air susu yang diambil.

\section{HASIL DAN PEMBAHASAN}

Data hasil pengamatan pengaruh penambahan baking soda terhadap gula darah, laktosa, dan produksi susu di sajikan pada Tabel 2.

Tabel 2. Rataan Gula Darah, Laktosa, Dan Produksi Susu Sapi Perah Laktasi

\begin{tabular}{llll}
\hline \multirow{2}{*}{ Parameter } & \multicolumn{3}{c}{ Perlakuan } \\
\cline { 2 - 4 } & \multicolumn{1}{c}{ T0 } & \multicolumn{1}{c}{ T1 } & \multicolumn{1}{c}{ T2 } \\
\hline Gula darah & $65.05 \pm 0.25$ & $61.94 \pm 0.75$ & $65.53 \pm 0.25^{\mathrm{ns}}$ \\
Laktosa & $4.04 \pm 0.03$ & $3.94 \pm 0.08$ & $4.09 \pm 0.12^{\mathrm{ns}}$ \\
Produksi susu & $12.95 \pm 0.25$ & $13.31 \pm 0.75$ & $12.65 \pm 0.05^{\mathrm{ns}}$ \\
\hline
\end{tabular}

\section{Gula darah}

Berdasarkan Tabel 2 terlihat bahwa kadar gula darah perlakuan pada kisaran 61,94 - 65,53 mg/dL, hal tersebut tergolong normal. Standar kadar gula darah yaitu 40,0 - 100,0 mg/dL (Mitruka dan Rawnsley, 1981).

Berdasarkan hasil analisis ragam kadar gula darah, terlihat bahwa suplementasi natrium bikarbonat pada perlakuan T1 dan T2 dengan dosis $0,8 \%$ dan $1 \%$ BK pakan tidak berbeda nyata terhadap kadar gula darah dibandingkan perlakuan T0. Tidak adanya pengaruh kadar gula darah tersebut diduga oleh kesamaan macam bahan pakan, bobot badan yang relatif seragam dan lingkungan. Parakkasi (1988) menambahkan bahwa salah satu yang mempengaruhi kadar gula darah adalah kualitas pakan, pakan yang berkualitas baik mempunyai tingkat konsumsi yang relatif tinggi dibanding pakan yang berkualitas rendah.

Rendahnya kadar gula darah juga dapat dipengaruhi oleh konsumsi bahan kering, konsumsi bahan kering yang tidak berbeda antara perlakuan T0, T1 dan T2 $(18,37 \pm 0,03),(19,79 \pm 0,05)$ dan $(20,04 \pm 0,07) \mathrm{kg} / \mathrm{ekor} / \mathrm{hari}$, juga dapat mempengaruhi kadar gula darah karena konsumsi BK pakan berbanding lurus dengan kadar gula darah. Anggorodi (1994) memperkuat bahwa kadar gula darah berbanding lurus dengan konsumsi bahan kering semakin tinggi konsumsi bahan kering semakin tinggi kadar gula darah.

\section{Laktosa susu}

Berdasarkan Tabel 2, kadar laktosa susu berkisar pada 3,94 - 4,09\% berada pada kisaran normal berdasarkan SNI (2011) yaitu pada kisaran 3,7-4,0 \% . Hal ini menunjukan bahwa laktosa susu sapi perlakuan berada pada kisaran angka normal, kemungkinan disebabkan oleh kesamaan sifat genetik. Menurut Schmidt (1988), persen kadar laktosa susu tidak berubah sesuai dengan sifat genetik ternak yaitu berkisar $2,5-5 \%$. 
Berdasarkan hasil analisis ragam, kadar laktosa susu yang tertera terlihat bahwa pakan yang disuplementasi natrium bikarbonat sebanyak 0,8\% dan $1 \% \mathrm{BK}$ pakan menunjukan tidak ada perbedaan nyata. Hal ini dapat terjadi dikarenakan kadar gula darah antara sapi yang tidak mendapat perlakuan dan mendapat perlakuan tidak berbeda nyata. Peningkatan kadar laktosa ini merupakan menifestasi meningkatnya aktivitas mikroba dalam mencerna zat makanan sebagai akibatnya peningkatan level mineral dalam rumen. $\mathrm{Ca}, \mathrm{P}$, dan $\mathrm{Mg}$ sangat penting dalam metabolisme dalam rumen, Dengan demikian pencernaan selulosa menjadi meningkat dan asam lemak terbang yang dihasilkan meningkat pula. Dengan meningkatnya asam lemak terbang, maka glukosa juga meningkat, karena asam lemak terbang khususnya asam propionat adalah prazat glukosa. Glukosa yang meningkat mengakibatkan kenaikan kandungan laktosa susu karena sebagaian glukosa akan masuk ke kelenjar mamae dan diubah menjadi laktosa (Arora, 1989).

Tinggi rendahnya laktosa susu juga dipengaruhi oleh konsumsi pakan, pakan yang mengandung asam propionat (C3) yang tinggi dapat meningkatkan kadar laktosa dalam susu karena asam propionat diubah menjadi glukosa dan glukosa merupakan prekusor utama pembentuk laktosa susu. Selain itu kadar laktosa susu dipengaruhi oleh asam amino bebas yang berasal dari suplementasi natrium bikarbonat, dimana natrium bikarbonat memberi pengaruh terhadap kandungan laktosa susu. Hal ini disebabkan natrium bikarbonat mampu memenuhi suplai asam amino di dalam sel sekretori untuk proses sintesis laktosa susu. Hal ini sesuai dengan pendapat Septadiana (2014) menyatakan bahwa natrium bikarbonat merupakan salah satu senyawa penyangga (buffer) yang mampu meningkatkan proses sintesa laktosa dalam ambing, galaktosa dan glukosa dibentuk menjadi laktosa oleh bantuan enzym lactose syntease.

\section{Produksi Susu}

Berdasarkan Tabel 2 terlihat bahwa besarnya produksi susu perlakuan berkisar antara 12,65 - 13,31 liter, produksi susu tersebut termasuk sedang, berada pada kisaran normal. Standar produksi susu sapi FH yaitu 10 - 15 liter/hari (Wijayanti, 2009). Faktor - faktor yang mempengaruhi produksi susu adalah jenis, bangsa, lingkungan, pakan, bulan laktasi, periode laktasi, dan faktor penyakit. Hal ini sesuai dengan pendapat Siregar (1993) yang berpendapat bahwa produksi susu sapi perah dipengaruhi oleh berbagai macam faktor diantaranya adalah jenis dan bangsa sapi, fisiologi lingkungan, pakan ternak, perkandangan, bulan laktasi dan periode laktasi.

Berdasarkan hasil analisis ragam produksi susu yang disuplementasi natrium bikarbonat sebanyak $0,8 \%$ dan $1 \%$ BK pakan tidak berbeda nyata dibandingkan dengan sapi yang tidak disuplementasi natrium bikarbonat (T0). Hal ini dikarenakan kandungan laktosa susu antara sapi yang tidak mendapat perlakuan dan sapi yang mendapat perlakuan tidak berbeda nyata, padahal antara laktosa dan produksi susu sangat erat hubunganya (berbanding lurus). Semakin tinggi kadar laktosa maka akan meningkatkan sekresi air susu karena laktosa merupakan faktor pembatas untuk sekresi susu. Hal ini sesuai dengan pendapat Tiffany., dkk (2006) yang menyatakan bahwa laktosa berperan penting dalam 
sekresi air susu, semakin tinggi kadar laktosa dalam susu maka semakin banyak pula air susu yang disekresi oleh kelenjar mamae.

\section{KESIMPULAN}

Suplementasi baking soda pada level 0,8 dan $1 \%$ BK tidak berpengaruh terhadap gula darah, laktosa, dan produksi susu sapi perah laktasi.

\section{DAFTAR PUSTAKA}

Anggorodi, R. 1995. Ilmu Makanan Ternak Umum. PT. Gramedia, Jakarta.

Arora, S.P. 1989. Pencemaran Mikroba Pada Ruminansia. Universitas Gadjah Mada Press. Yogyakarta.

Benerjee. 1982. Text Book of Animal Husbandry. Ed 5 th. Oxford IBH Publishing Co. New Delhi.

Mitruka, B. M. and Rawnsley, H. M. 1981. Clinical Biochemical and Hematological Reference Values in Normal Experimental. Animal and Normal Human New York. Masson Pub. USA.

Parakkasi, A. 1988. Ilmu Nutrisi dan Makanan Ternak Ruminan. Universitas Indonesia Press, Jakarta.

Schmidt, G.H. 1988. Biology of Lactation. W.H. Freeman and Company, San Fransisco.

Suhendar. 2008. Pasca Panen Lalai Kualitas Susu Terbengkalai. Institut Mikrobiologi Pangan. Bandung.

Sumudhita. 1989. Susu dan Penanganannya. Prodi Ilmu Produksi Ternak Perah. Fakultas Peternakan Universitas Udayana. Denpasar.

Siregar, S. B. 1993. Jenis, Tekhnik Pemerahan dan Analisis Usaha Sapi Perah. Penebar Swadaya. Jakarta.

Tillman, A.D., H. Hartadi, S. Reksohadiprojo, S. Prawirokusumo, S. Lebdosoekodjo. 1984. Ilmu Makanan Ternak Dasar. Cetakan Ketiga. Gajah Mada University Press, Yogyakarta.

Wijayanti, S. 2009. Identifikasi dan Pemeriksaan Jumlah Total Bakteri Susu Sapi Segar. Fakultas Farmasi Universitas Muhammadiyah Surakarta. Surakarta. 